\title{
Eras and Reigns During Sōchō's Lifetime (1448-1532)
}

Era

Bun'an 文安 I444

Hōtoku 宝徳 I449

Kyōtoku 享徳 I452

Kōshō 康正 I455

Chōroku 長録 I457

Kanshō 寛正 I46I

Bunshō 文正 I466

Ōnin 応仁 1467

Bunmei 文明 I469

Chōkyō 長享 I487

Entoku 延徳 I489

Meiō 明応 I492

Bunki 文亀 I5OI

Eishō 永正 I5O4

Daiei 大永 I52I

Kyōroku 享録 I528

Tenbun 天文 I532
Emperor

Gohanazono 後花園

$$
\text { I4I9-7I (r. I428-64) }
$$

Ashikaga Yoshimasa 足利義政

$$
\text { I436-90 (r. I449-74) }
$$

Gotsuchimikado 後土御門

$$
\text { I442-I5OO (r. I464-I5OO) }
$$

Ashikaga Yoshihisa 足利義尚 I465-89 (r. I474-89)

Ashikaga Yoshitane 足利義植 I466-I523 (r. I490-I5OI?)

Ashikaga Yoshizumi 足利義澄 I48I-I5II (r. I494-I5II)

Gokashiwabara 後柏原 I464-I526 (r. I500-26)

Gonara 後奈良 I497-I557 (r. I526-57)
Ashikaga Yoshitane 義植 (r. I5O8-2I)

Ashikaga Yoshiharu 足利義晴 I5II-5O (r. I522-I547) 
